\title{
A STUDY OF THE SONIC RESONANCE OF THE FEMORAL PART OF HIP ENDOPROSTHESIS
}

\author{
ŠTUDIJA ZVOČNE RESONANCE STEGNENIČNEGA DELA \\ KOLČNE PROTEZE
}

\author{
Igor Belič ${ }^{*}$, Beno Klopčič², Andraž Logar², Monika Jenko ${ }^{1,3}$, Drago Dolinar ${ }^{4,3}$, \\ Matevž Gorenšek ${ }^{5,3}$, Boštjan Kocjančič ${ }^{4}$ \\ ${ }^{1}$ Institute of Metals and Technology, Lepi pot 11, 1000 Ljubljana, Slovenia \\ 2BOSCH REXROTH d.o.o., Kidričeva 81, 4220 Škofja Loka, Slovenia \\ ${ }^{3}$ MD-RI Institute for Materials Research in Medicine, Bohoričeva Street 5, 1000 Ljubljana, Slovenia \\ ${ }^{4}$ Department for Orthopaedic Surgeon, University Medical Centre Ljubljana, Zaloška 9, 1000 Ljubljana, Slovenia \\ ${ }^{5}$ MD-Medicina Ljubljana, Bohoričeva Street 5, 1000 Ljubljana, Slovenia \\ Prejem rokopisa - received: 2020-06-09; sprejem za objavo - accepted for publication: 2020-07-24
}

Mechanical resonance is the property of a mechanical system that responds to the oscillations coming from the outside of the observed system. The response amplitude of the system is the highest when the frequency of the oscillations matches the system's natural frequency (its resonance frequency). It is known that resonance can cause swaying motions and even catastrophic failure in improperly constructed structures. The phenomenon is known as resonance disaster. Sonic energy enters the system through excitation and is dissipated through damping. Damping can be internal (within the material) or external (mounting of an object). Six retrieved stems of hip endoprostheses were studied. For each of them sonograms were made, showing very distinctive and narrow resonance curves with one major resonance peak followed by several higher harmonic peaks. Simulation of endoprostheses standing waves was also performed resulting in the demonstration of various standing wave modes depending on the observed frequency. Results clearly show that, due to the geometry and the used material, the observed endoprostheses have very distinctive sonic resonance characteristics. The resonance is excited by the sound coming from outside (or inside) of the human body. The energy of resonance movement of the endoprosthesis is dissipated through the endoprosthesis-bone interface. A long-term exposure to the resonance oscillations might contribute to other causes of aseptic loosening of endoprostheses.

Keywords: femoral part of hip endoprosthesis, vibration analysis, resonance, aseptic loosening

Mehanska resonanca je lastnost sistema, ki se odziva na zvočna nihanja, izvirajoča iz zunanjosti opazovanega sistema. Amplituda odziva sistema je največja, če se frekvenca nihanj ujema z naravno frekvenco sistema (njegova resonančna frekvenca). Znano je, da lahko resonanca povzroči zvijanje sistema ali celo porušitev pri nepravilno načrtovanih konstrukcijah. Pojav je znan kot resonančna katastrofa. Zvočna energija vstopi v sistem z vzbujanjem in se disipira z dušenjem. Dušenje nihanja je lahko notranje (znotraj sistema) ali zunanje (vpetje - namestitev sistema). Śtudirali smo šest stegneničnih delov endoprotez kolka. Za vsakega od njih so bili narejeni sonogrami, ki prikazujejo zelo izrazite in ozke resonančne krivulje z enim glavnim resonančnim vrhom, ki mu sledi več višje-harmonskih vrhov. Izvedena je bila tudi simulacija stoječih valov, ki so pokazale različne načine stojnega valovanja in sicer glede na opazovano frekvenco. Rezultati jasno kažejo, da imajo endoproteze zaradi geometrije in uporabljenega materiala zelo izraženo zvočno resonanco. Resonanco vzbuja zvok, ki prihaja od zunaj (ali znotraj) človeškega telesa. Energija resonančnega gibanja endoproteze se disipira preko spoja endoproteza-kost. Stalna izpostavljenost resonančnim nihanjem še dodatno prispeva k aseptičnemu omajanju endoprotez.

Ključne besede: stegnenični del proteze kolka, vibracijska analiza, resonanca, aseptično popuščanje

\section{INTRODUCTION}

\subsection{Known causes for the aseptic loosening of endo- prostheses}

There are many reasons for aseptic loosening of endoprostheses. There are also several theories about the causes of aseptic loosening (i.e., osteolysis) resulting in loosening of the implant. ${ }^{1}$

Particle disease. The particle disease theory is currently the prevailing one. Endoprosthesis wear products directly activate macrophages and osteoclasts, thus initiating the bone resorption. The bone resorption enlarges the interface volume between the bone and endoprosthesis, leading to higher joint fluid flows, providing

*Corresponding author's e-mail:

igor.belic@imt.si (Igor Belič) higher transportation capacity of the wear material. The consequence of the process is the loosening of the implant. ${ }^{1,2}$

Cement. Possible problems with PMMA cement (polymethylmethacrylate) are wear related. The first problem is de-bonding, another one is cracking, which produces debris in a joint region. Aging of the cement causes it to become more brittle, and thus the possibility of cracking becomes higher. ${ }^{3}$

Polyethylene. UHMWPE (ultra-high-molecular-weight polyethylene) is the most common material for an endoprosthesis bearing. It was found out that the particles UHMWPE alone could cause bone resorption, even in the absence of motion and infection. ${ }^{1,4,5}$

Metal. Metal-to-metal implants exhibit less wear than metal-to-UHMWPE implants. Titanium alloys have 
reduced the risk of debris production to a minimum. Metal particles also cause grinding wear, producing more and more wear particles. Metal particles are considered to have the capacity to participate in the processes leading to aseptic loosening. ${ }^{5}$

Ceramic. Even if the amounts of ceramic particles are generally small, they are also being considered as possible generators of aseptic loosening. 5,6

Micromotion. This is the phenomenon that describes small movements between an implant and the surrounding bone. The actual registration of implant movement is the consequence of many prior events that led to such a situation. Micromotion is a consequence of a bad osseointegration or cement de-bonding. References reveal that even a short daily micromotion period suffices to prevent osseointegration. ${ }^{1,7}$

Stress shielding. Stress shielding refers to the bone structure's adaption according to the load. Implant produces new loading conditions to the bone, which can lead to bone loss around the implant. In such cases the osteolysis is caused by the bone adaption to the newly emerged load conditions. ${ }^{8,9}$

High fluid pressure. Oscillating joint fluid pressure might affect the interstitial osteoclasts and osteoblasts, leading to bone loss, thus producing osteolysis. ${ }^{10}$

Individual or genetic variations. There are individual genetic variations that lead to the very adverse cellular responses on such issues as particle disease, stress shielding and high fluid pressure. Such variations are to some extent responsible for implant-loosening processes. ${ }^{11,12}$

Sealed interface. Wear products can affect the interfaces around implants. Sealing off the interface is very important for the longevity of the implant. Early micromotion affects the sealing of the interface. ${ }^{1}$

Recent research of our group added further issues that might contribute to the aseptic loosening of an implant. ${ }^{13}$

Remnants of the implant surface sand blasting. Implants are sand blasted to provide better osseointegration. The implant surface thus becomes very rough. The small sand particles remain on the rough surface and are later added to other particles in the joint liquid.

Small cavitation on the surface. It was shown that the sand-blasting process produces small cavitation on the implant surface, which can hypothetically induce many problems regarding the implant's lifetime.

\subsection{Mechanical resonance}

There is another issue that might add up to the already-known causes of implant failures. The femoral part of the hip endoprosthesis is quite a large piece of metal. Unfortunately, it exhibits a very distinctive acoustic resonance very much comparable to a music fork. If one strikes it with the metal rod, it clings with a very clear and loud sound of several $\mathrm{kHz}$. We have decided to make a preliminary study of the mechanical resonance of the femoral part of the hip implant. ${ }^{14}$

Mechanical resonance is the property of a mechanical system that responds to the oscillations coming from the outside of the observed system. The response amplitude of the system is the highest when the frequency of oscillations matches the system's natural frequency (its resonance frequency).

The idealized model that tries to explain the behaviour of an ideal mechanical system is composed of elements such as mass, spring, damper and excitation. The first three elements describe the physical system. Energy is stored by the system in the mass and the spring in the form of kinetic and potential energy. Energy enters the system through excitation and is dissipated through damping. Damping can be internal (within the material) or external (mounting of an object). ${ }^{15}$

Sonic energy enters the system through excitation and is dissipated through damping. ${ }^{15}$

In our case the mechanical system represents the femoral part of the hip implant. Once inserted, the sonic energy enters the implant through the human body, the sonic energy is dissipated through the implant/bone interface.

Modal analysis is a scientific field devoted to the study of the dynamic characteristics of mechanical structures. ${ }^{16}$

In this paper we would like to pay attention to the phenomenon of acoustic resonance of the hip endoprosthesis, which by our opinion, might have the potential to contribute to other causes of aseptic loosening. The paper is not meant as in-depth study of the phenomenon.

\section{EXPERIMENTAL PART}

Six retrieved stems* of hip endoprostheses were studied. For each of them sonograms were taken, using a wide frequency range USB microphone connected to a $\mathrm{PC}$ to capture the sound signal. The registered signals were analysed with the Octave 4.2.1. software, by which the Fourier transform of the sound signal was calculated, transforming the time domain signal to the frequency domain. The acoustic signal transformed to the frequency domain was then graphically presented in sonograms (frequency/amplitude/time), again using Octave software.

The next step was the simulation of the endoprostheses' vibrational dynamics. The purpose of the research was to establish the swaying motion of implants that might contribute to loosening of the implant. Femoral parts were $3 \mathrm{D}$ scanned and the vibrational properties were studied with the Creo 4.0 software.

\footnotetext{
*Due to our previous research we were in possession of the retrieved stems. The study could have been carried out on a new stems as well.
} 


\section{RESULTS AND DISCUSSION}

\subsection{Measurements of resonance}

Sonograms show very distinctive and narrow resonance curves with one major resonance peak $(2323 \mathrm{~Hz})$ followed by several higher harmonic peaks (Figures 1 and 2).

From Figures 1 and $\mathbf{2}$ it is clear that the main resonance frequency at $2323 \mathrm{~Hz}$ remains active for a very long time, while higher harmonic frequencies decay faster. The resonance phenomenon happens because of favourable conditions that are met by the given material density and the geometrical shape of the femoral part. Both conditions define the sonic oscillations at the resonance frequency. Generally, there are two possibilities to avoid the resonance. First, is the choice of material, which because of the other properties that are required for the implant, is very much limited. The density of the material can be controlled though the porosity (something that can be compared to the bone structure) and can nowadays be achieved using 3D-printed metals. Another

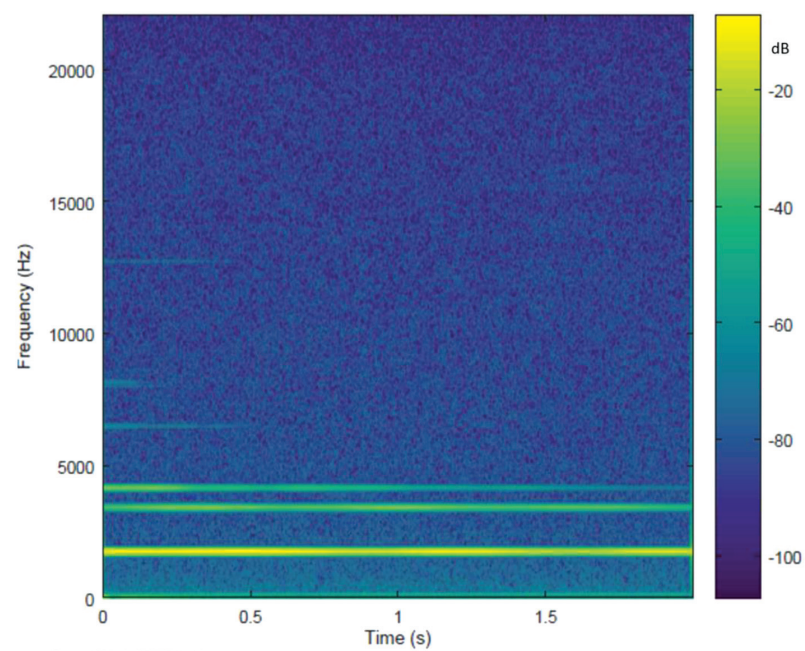

Figure 1: Sonogram of a femoral part of hip endoprosthesis. The sound was excited by striking the femoral part with a metal rod.

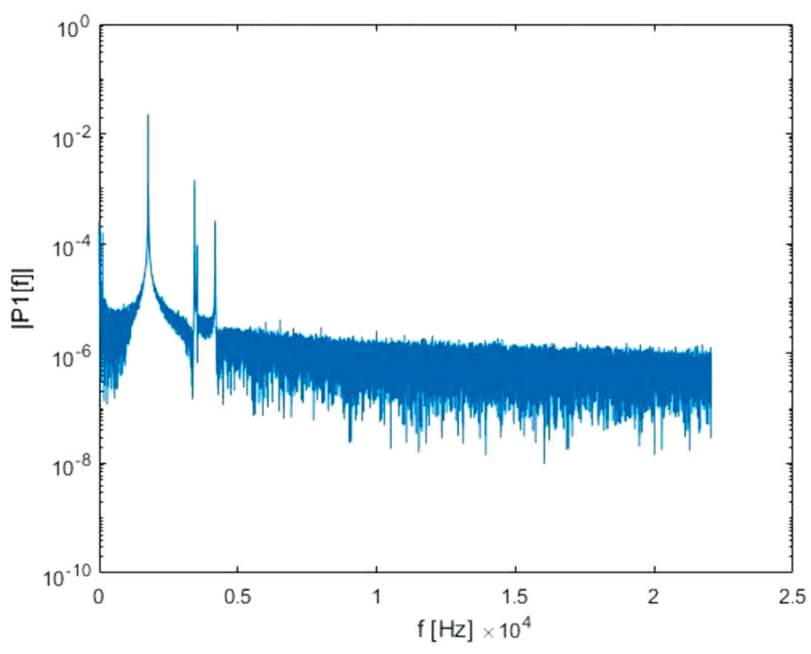

Figure 2: Frequency spectra of the oscillations of a femoral part.
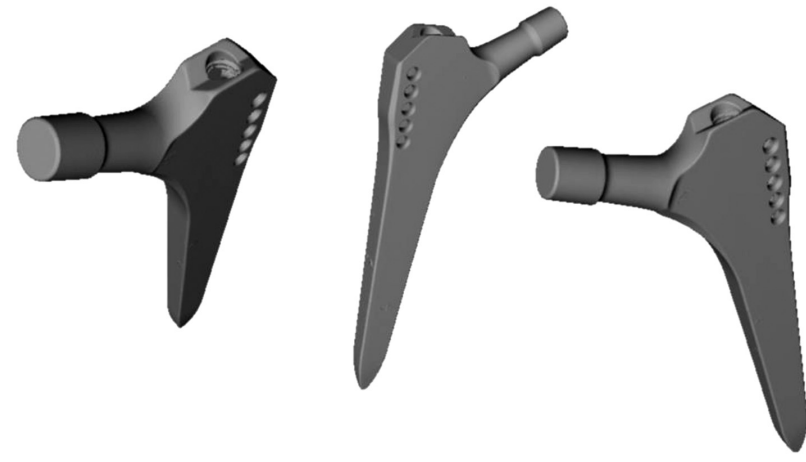

Figure 3: 3D scanned femoral part of a hip endoprosthesis.

choice to avoid the resonance is the geometry of the implant. Again, the shape of the implant does not give much free space. The only reasonable solution seems to be the $3 \mathrm{D}$ printed internally porous titanium alloy implant with a non-porous surface. Such a structure does not have a distinctive resonance frequency.

\subsection{Simulation of the femoral part's oscillation}

To simulate the oscillation of the femoral part of the hip endoprosthesis, samples were scanned by a 3D scanner. The geometric structure was captured (Figure 3) and the simulation of its oscillation was performed.

From Figures $\mathbf{4}$ and $\mathbf{5}$ it is clear that the standing waves produce different oscillating amplitudes at different places of a femoral hip endoprosthesis (red colour represents high amplitude while the dark blue colour represents low amplitude). The problem that occurs is that the resonance frequency produces high oscillation amplitudes always at the same places on the endoprosthesis.

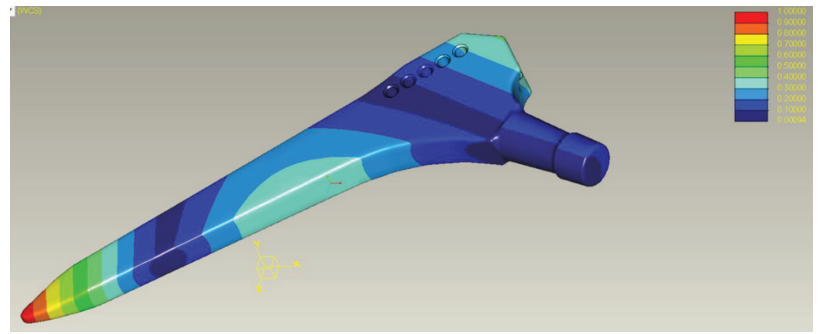

Figure 4: Simulated standing waves of the oscillated femoral endoprosthesis at $2323 \mathrm{~Hz}$. The colour represents the relative amplitude of the oscillation.

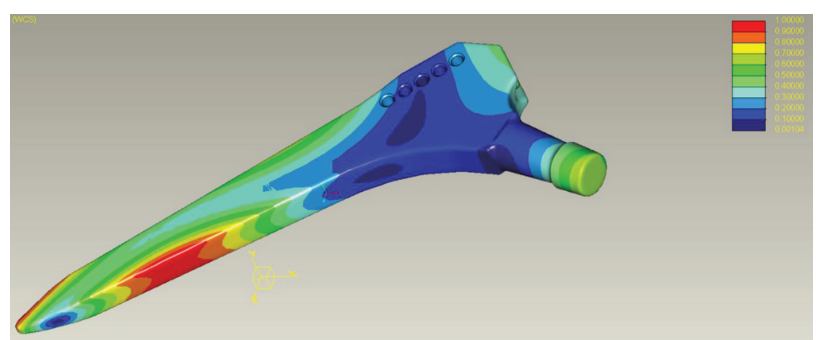

Figure 5: Simulated standing waves of the oscillated femoral endoprosthesis at $7170 \mathrm{~Hz}$. The colour represents the relative amplitude of the oscillation. 


\section{BELIČ et al.: A STUDY OF THE SONIC RESONANCE OF THE FEMORAL PART OF HIP ENDOPROSTHESIS}

Since the endoprosthesis is mounted in a bone tissue, the same places in the bone are being constantly subjected to grinding. The rough surface of the endoprosthesis, which is purposefully being roughened in order to provide better osseointegration, due to the vibration, effectively grinds the bone. The problem with a resonant endoprosthesis is that it is constantly being subjected to the sound that is originating in a human body or it is coming from the outside. The resonator picks the sounds and oscillates at the resonance frequency.

Another problem that was revealed by the simulation is that the endoprosthesis actually sways because of the sonic resonance. The phenomenon is an extremely interesting one and might additionally worsen the conditions at the implant/bone interface.

The results clearly show that, due to the geometry and the used material, the observed endoprostheses have very distinctive sonic resonance characteristics. The resonance is excited by the sound coming from the outside (or inside) of the human body, from body movements (walking, etc.). The energy of the resonance movement of the endoprosthesis is dissipated through the endoprosthesis-bone interface. A long-term exposure to the resonance oscillations adds to other causes of aseptic loosening of the endoprostheses.

\section{CONCLUSIONS}

Femoral parts of the hip endoprosthesis exhibit a very distinctive and narrow sonic resonance with one major resonance frequency followed by several higher harmonics.

The results clearly show that, due to the geometry and the used material, the observed endoprostheses have very distinctive sonic resonance characteristics.

The resonance is excited by the sound coming from outside (or inside) of the human body and from the body's movement.

The energy of the endoprosthesis resonance is dissipated through the endoprosthesis-bone interface.

A long-term exposure to the resonance oscillations might contribute to other causes of aseptic loosening of endoprostheses.

The only reasonable solution to avoid resonance seems to be a 3D-printed, internally porous, titanium-alloy implant with a non-porous surface. Such a structure does not have a distinctive resonance frequency.

\section{Acknowledgement}

This work was supported by the Slovenian Research Agency Programme group P2-0056.

\section{REFERENCES}

${ }^{1}$ M. L. V. Carlsson, C. B. Johansson, P. Thomsen, C. Gretzer, Aseptic loosening, not only a question of wear A review of different theories, Acta Orthopaedica, 77 (2006) 2, 177-197, doi:10.1080/ 17453670610045902

${ }^{2}$ J. Gallo, S. B. Goodman, Y. T. Konttinen, M. Raska, Particle disease: Biologic mechanisms of periprosthetic osteolysis in total hip arthroplasty, Innate Immun, 19 (2013) 2, 213-224, doi:10.1177/ 1753425912451779

${ }^{3}$ N. Verdonschot, R. Huiskes, Cement debonding process of total hip arthroplasty stems, Clin. Orthop. Relat. Res. 3 (1997) 336,297-307, doi:10.1097/00003086-199703000-00038

${ }^{4}$ R. A. Cooper, C. M. McAllister, L. S. Borden, T. W. Bauer, Polyethylene debris-induced osteolysis and loosening in uncemented total hip arthroplasty, A cause of late failure, J Arthroplasty, 7 (1992) 3, 285-90, doi:10.1016/0883-5403(92)90050-Z

${ }^{5}$ D. Bitar, J. Parvizi, Biological response to prosthetic debris, World J. Orthop., 18(2015)2, 172-189, doi:10.5312/wjo.v6.i2.172

${ }^{6}$ E. Sukur, Y. E. Akman, Y. Ozturkmen, F. Kucukdurmazc, Particle Disease: A Current Review of the Biological Mechanisms in Periprosthetic Osteolysis After Hip Arthroplasty, Open Orthop J., 10 (2016) 241-251, doi:10.2174/1874325001610010241

${ }^{7}$ U. Chong, A. Desmond, A. Hansen, Analysis of bone-endoprosthesis interface micromotion for cementless tibial endoprosthesis fixation and the influence of loading conditions, Journal of biomechanics, 43 (2010) 1074-1080, doi:10.1016/j.jbiomech.2009.12.006

${ }^{8}$ B. A. Behrens, C. J. Wirth, H. Windhagen, I. Nolte, A. MeyerLindenberg, A. Bouguecha, Numerical investigations of stress shielding in total hip endoprostheses, Proc. Inst. Mech. Eng. H, 222 (2008) 5, 593-600, doi:10.1243/09544119JEIM139

${ }^{9}$ B. Cheruvu, I. Venkatarayappa, T. Goswami, Stress Shielding in Cemented Hip Implants Assessed from Computed Tomography, Biom. Jour. of Sci. Tech. Res., 18 (2019) 3, 13637-13641, doi:10.26717/ BJSTR.2019.18.003163

${ }^{10}$ A. Fahlgren, M. P. Bostrom, X. Yang, L. Johansson, U. Edlund, F. Agholme, P. Aspenberg, Fluid pressure and flow as a cause of bone resorption, Acta Orthop. 81 (2010) 4, 508-516, doi:10.3109/ 17453674.2010.504610

${ }^{11}$ Y. Yan, J. Hu, H. Lu, W. Wang, Genetic susceptibility to total hip arthroplasty failure: a case-control study on the influence of MMP 1 gene polymorphism, Diagn. Pathol., 9 (2014) 177-179, doi:10.1186/ s13000-014-0177-9

${ }^{12}$ A. Del Buono, V. Denaro, N. Maffulli, Genetic susceptibility to aseptic loosening following total hip arthroplasty: a systematic review, British Medical Bulletin, 101 (2012) 1, 39-55, doi:10.1093/bmb/ ldr011

${ }^{13}$ K. Avsec, M. Jenko, M. Conradi, A. Kocijan, A. Vesel, J. Kovač, M. Godec, I. Belič, B. Šetina Batič, Č. Donik, M. Gorenšek, B. Kocjančič, D. Dolinar, Surface Properties of Retrieved Cementless Femoral Hip Endoendoprostheses Produced from a Ti6A17Nb Alloy, Coatings, 8 (2019) 868, doi:10.3390/coatings9120868

${ }^{14}$ I. Belič, B. Klopčič, A. Logar, M. Jenko, D. Dolinar, M. Gorenšek, B. Kocjančič, Mechanical Resonance of Femoral Part of Hip Endoprosthesis as Possible Cause of Aseptic Loosening, Proc. of the $27^{\text {th }}$ International Conference on Materials and Technologies, Portorož, Slovenia, 2019

${ }^{15}$ A. A. Shabana, Theory of Vibration: An Introduction (Mechanical Engineering Series), Vol. 1, $2^{\text {nd }}$ Ed., Springer, Berlin, p. 350, 1995

${ }^{16}$ The Fundamentals of Modal Testing, Application Note $243-3$, Agilent Technologies, http://www.modalshop.com/techlibrary/Fundamentals\%20of\%20Modal\%20Testing.pdf, 20.12.2019 